\title{
Machinery and Technical Efficiencies in Selected Paddy Areas in Malaysia
}

\author{
Siti 'Aisyah Baharudin and Hayyan Nassar Waked* \\ Department of Economics, School of Social Sciences, Universiti Sains Malaysia, 11800 Pulau Pinang, Malaysia
}

\begin{abstract}
Malaysia's paddy sector frequently relies on machinery in its activities, from land preparation until harvesting. However, the shortfall of meeting domestic demand, ineffective use of machinery, mismanagement, and technical inefficiency were among the sector's challenges. This study analyses the socio-economic effect on machinery and technical efficiencies in Malaysia's Muda Agricultural Development Authority (MADA) and Integrated Agricultural Development Area Barat Laut Selangor (IADA BLS) paddy areas. Qualitative data were collected using a face-to-face interview. The results confirmed that MADA respondents were highly trained, more educated, and more efficient in using machinery in the agriculture sector than IADA BLS. The same goes for MADA's productivity, energy outputs, machinery efficiency, labour, and technology use, which were higher than IADA BLS. However, inadequate planning and managing farm activities led to poor paddy field conditions, including insufficient water supply system, irregularly shaped paddy field plots, and increasing difficulties in handling paddy diseases and maintaining the machinery. These challenges resulted in a frequent interruption of paddy production activities, incurring additional costs, decreasing profit, and jeopardising the farmers' financial status. Therefore, it is recommended to use types of machinery that fit a particular purpose in terms of cost and technology and ensure the required services are carried out on time to maximise machinery efficiency. On the other hand, technical efficiency's main challenges were the high operation cost and increasing fossil fuel use, combined with a lack of government subsidies.

ARTICLE INFO

Article history:

Received: 17 December 2020

Accepted: 07 May 2021

Published: 12 November 2021

Research and development in agricultural energy use, environment, and government subsidies could decrease production costs and improve paddy production.
\end{abstract}

DOI: https://doi.org/10.47836/pjssh.29.4.07

$\overline{\text { E-mail addresses: }}$

sab16@usm.my (Siti 'Aisyah Baharudin)

Hayyan_waked@hotmail.com (Hayyan Nassar Waked)

* Corresponding author
Keywords: Farming efficiency, Malaysia, paddy production, socio-economic characteristics 


\section{INTRODUCTION}

Agriculture is an important sector in Malaysia. It plays a crucial role in producing agricultural products for domestic consumption and contributes to its national Gross Domestic Products (GDP). According to Selected Agricultural Indicators, Malaysia, 2019, the agricultural sector contributed $7.3 \%$ (RM 99.5 billion) to GDP in 2018, with oil palm as the primary contributor $(37.9 \%)$, followed by other agriculture (25.1\%), livestock (14.9\%), fishing (12.5\%), forestry and logging $(6.9 \%)$ and rubber $(2.8 \%)$. The statistics were presented in three primary agriculture sub-sectors, namely crops, livestock, and fisheries. The paddy production saw a $2.7 \%$ increase from 2,570 thousand tonnes to $2,639.9$ thousand tonnes within the crops sub-sector. On the other hand, the production of natural rubber and oil palm declined $18.5 \%$ and $3.3 \%$, respectively, in 2018 (Mahidin, 2019).

Rice is a staple food in Malaysia as Malaysian consumption is estimated at 73.9 kilograms of rice per year. Approximately $63 \%$ of 2.4 million MT of rice consumed by Malaysians in 2019 were produced domestically, while the rest was imported. Based on 2019 data, 192,663 farmers in Malaysia produced 2.3 million tonnes (MT) with a paddy planted area of 672,084 hectares (ha). Paddy grains from the harvested paddy were sold to 157 rice millers at a Guaranteed Minimum Price (GMP) of RM 1,200/MT, who processed them into 1.5 million MT of rice and later distributed the rice in 56,746 retail stores through 1,660 wholesalers
(Ministry of Agriculture and Food Industries [MAFI], 2020). This typical flow in paddy production shows that a proper supply chain management system is critical for efficient procurement, manufacturing, distribution, and retailing and thus fulfilling consumer demands without facing a situation of lost sales. Farmers as paddy suppliers, agents, rice millers, distributors, and retailers typically comprise the upstream and downstream stages and traditional rice supply chain management. However, the increase in the nation's population and the decrease in agricultural land and land usage for agro-food crops might pose security concerns. Therefore, to achieve the targeted Self-Sufficiency Level (SSL) each year, the government has formulated relevant agricultural policies (Omar et al., 2019; Dardak, 2019). As a result, the targeted paddy's SSL is set to increase from $73 \%$ in 2020 to $75 \%$ in 2025 in an attempt to safeguard the country's food security while reducing its dependency on imported foods (The Star, 2019).

The shortfall of meeting domestic demand in rice commodities production is one of the most severe challenges in this sector (Khor, 2008). The lack of supply could increase market prices, adversely affecting consumer welfare (Alam et al., 2010a). $71.4 \%$ (1.5 million metric tonnes) of domestic rice production was sourced from 391,104 ha of granary areas. Eight leading agencies are involved in the rice productions in Malaysian granary areas, namely Muda Agricultural Development Authority (MADA) in Kedah, Integrated 
Agricultural Development Area (IADA) Sungai Manik and IADA Seberang Perak in Perak, IADA Balik Pulau in Penang, Lembaga Kemajuan Pertanian, Kemubu Agriculture Development Authority (KADA) and IADA Kemasin Semerak in Kelantan, Northern Terengganu Integrated Agricultural Development Area (IADA Ketara) in Terengganu, and IADA Barat Laut Selangor in Selangor (BLS) (Rahmat et al., 2019). Given the differences in their locations because of environmental conditions, farm practices and various paddy production factors, these granary areas have different paddy productivity levels. The current national paddy productivity (average yield) is around 4.0 MT/ha compared to potential yield at 7.0 MT/ha with high performing areas such as IADA BLS and MADA, with yields above 5.0 MT/ha. On the contrary, granaries such as IADA Kemasin Semerak and Ketara have the lowest paddy productivity, with average yields below 3.0 MT/ha (MAFI, 2020).

In Malaysia, the paddy sector frequently relies on machinery in each activity, from land preparation until harvesting. Efficient machinery increases the productivity of paddy. However, high maintenance of machinery, at a high cost, is required for machinery use. Apart from that, the supplier or machinery owners have consequences when poor machinery management is performed. Heavy and oversized machines such as combine harvesters could damage the land. On the other hand, technical efficiency needs to be carried out to find the effectiveness of a given set of inputs when used to produce an output. An organisation is technically efficient if it produces the maximum output from the minimum quantity of inputs, such as labour, capital, fuel, and machinery. Hence, studies on machinery efficiency and technical efficiency are essential to address these issues. MADA and IADA BLS granary areas are used in this study; IADA BLS has higher productivity while MADA has a higher harvested paddy area in Malaysia. This study analyses the socio-economic effect on machinery and technical efficiencies in Malaysia's MADA and IADA BLAS paddy areas. The motivation of the study is aligning with the government's agricultural policies to achieve SSL of paddy production each year due to food security concerns.

\section{LITERATURE REVIEW}

Mechanisation is the process of shifting from working exclusively or mainly by hand to utilising machinery. It comes with many benefits, including improving labour efficiency, increasing production and the yield of land per unit of area, reducing the number of required labours, lowering the cost of work, units, and production, and bringing improvements in agricultural technique (Pingali, 2007). However, mechanisation also has disadvantages, such as soil compaction by heavy machines and displacement of workers, particularly unskilled labourers (Pryor et al., 2017), a higher cost of maintenance, and environmental concerns (Yu, 2013). Agriculture mechanisation goes into three stages. The first stage enhances agricultural 
technology's integrated application. The rapid growth of agricultural cooperatives has effectively enhanced agricultural production organisation, facilitated the shift of rural labour-power, and enhanced agricultural technology's integrated implementation. It has facilitated cost reduction, improved efficiency and agricultural scale operation, and improved farm equipment and agronomy integration. The second stage focuses on strengthening Research and Development (R\&D) on agricultural mechanisation technology and equipment. Significant signs of progress are seen in extensive horsepower tractor development and rice planting and harvesting machinery equipment. Agricultural machinery is crucial in agricultural production to maintain stable farming land, improve yield, catch season, and prevent disaster, contributing to farmers' continuous food production and income growth. The last stage spotlights the importance of advanced mechanical power. Due to the internationalisation of the domestic market and demand sophistication, locally owned firms would have to compete with large manufacturers of products, particularly in global technology (Garcia, 2008).

\section{Socio-economic in Paddy Production}

Farmers' socio-economic characteristics play a vital role in paddy yields (Alam et al., 2010b). Kedah is Malaysia's most prominent state in terms of the paddy territory contrasted with different states. The government is working on shrinking the socio-economic gaps. Infrastructure improvement is needed in the Muda area's water system territory to increase development efforts, primarily when water management and water resources are utilised proficiently on a continuous premise. Socioeconomic patterns of farmers in the Muda have been divided into several groups for gathering that includes paddy ranchers gathering that plays and provides important outputs to policymakers (Hussin \& Mat, 2013). Climate changes also may cause severe socio-economic impacts and imperil the future food security of a country. The growth and yield of paddy cultivated in these regions are strongly influenced by either positive or negative rainfall (Alam et al., 2010c). Implementing adaptive measures will significantly help reduce the adverse impacts of climate change, and the farmers will be ready to cope with uncertainties brought about by climate change (Chithranayana \& Punyawardena, 2008). The likelihood of using agricultural inputs increases with education, crop production, livestock, and farm incomes. It decreases with the total number of livestock and non-farm income owned by a household. Non-farm income is comprised of average annual income from employment wage and remittance from relatives, while farm income refers to income accrued from crop sales. Age, gender, and marital status of the household head and size of land owned by the household were likely to be influenced.

These variables allow the utilisation of agricultural inputs in paddy production (Boniphace et al., 2015). Man (2009) 
states that financial, social, and human factors improve farmers' well-being. In Malaysia, about 300,000 rice farmers relied on rice cultivation as their primary income source in 2009. Rice farmers are typically settled around the peninsula in eight main granaries and other small granaries. Poverty is usually synonymous with the farming community, particularly the rice farming community, mainly of Bumiputera. A lack of productive assets, active depending on small-scale farming projects and non-agricultural activities, appears to be among the recognised reasons for poverty afflicting the local rice farming community. The occurrence of hardcore poverty and income inequality among farmers, particularly Bumiputera, has, for decades, attracted policymakers' attention in formulating policies to avoid such incidents that constantly fetter rural communities (Fahmi et al., 2013).

\section{Machinery Efficiency}

Machinery efficiency is the machine's ability to avoid wasting inputs such as fuel and electricity to produce the desired result and maximise the yield. The machine requires energy as an essential input to production. Energy is used to perform crop production processes such as postharvest, land preparation, planting, and crop management. Energy use depends on the level of mechanisation, energy price, the number of active workers, and the cultivability of land (Baharudin \& Arshad, 2014). Noor and Hussein (1986) stated that farmers and contractors are encouraged to update their machinery equipped with new technologies to increase paddy production. They also found no difference between economic, technological, and allocative efficiencies in large-scale or small-scale farmers in Malaysia. Malaysia's paddy industry has generated stable revenues for the country. This generation of income reflected this industry's success. Tewari et al. (2012) found the high ranked paddy productivity in the State of West Bengal large farms because its mechanisation index is the highest. Due to the labour shortage, the state ensured machinery availability, increasing machinery used in paddy transplanters. Farmers were identified as related to the agriculture sector. Income and consumption habits were found to be below average. Major occupations were teaching, fishing, and day-to-day wage earners. Most of the rice farmers were tenants, uneducated, and men usually were taken decisions. Farmers produced their food with their farm products, such as cattle, buffalo, cow, and poultry were the primary lives (Alam et al., 2010b).

\section{Technical Efficiency}

Technical efficiency is the effectiveness with which a given set of inputs, such as labour, capital, and technology, can produce an output. The efficiency measurement in agricultural production determines the efficiency level of input and output in paddy planting activities. Farmers in developing countries do not use all potential technological resources, making inefficient agricultural activities (Khai \& Yabe, 2011). 
Project theory of change simplified the reconstruction of critical infrastructure to increase productivity and income from agricultural products. For example, some communities have undertaken significant work to repair and rehabilitate existing dams and irrigation schemes. It allows paddy farmers to increase their growing season to generate additional harvests and, hence, higher income and ensure food safety. Additional infrastructure works, including the renovation of key access routes, were designed to improve access to farmers' markets and suppliers. The project also established large-scale infrastructure works (Livelihoods Outcome Indicator, 2013). Yagi and Hayashi (2020) investigated the technical efficiency of relatively largescale rice farms in Japan to estimate the organisations' impact on the number of machines and machine working days. They found that non-family farms were able to utilise machinery efficiency highly with a grander operation scale.

\section{MATERIALS AND METHOD}

The study areas of this research are in two Malaysian states. MADA is in Pendang and Kota Sarang Semut regions in Kedah state. IADA BLS is in Sabak Bernam and Kuala Selangor regions in Selangor state. These two study locations were chosen because MADA has the largest paddy area representing $35.13 \%$ of Malaysia's total paddy areas (MADA, 2019), and IADA BLS has the highest paddy productivity in Malaysia, accounting for more than 5.0 MT/ha (IADA, 2019). This study uses qualitative data sources such as observation, semi-structured interviews, and document analysis. The researchers visited the study site and conducted a field study to obtain relevant information and data. This study conducted 12 pilot surveys, and 40 respondents participated from each area (MADA and IADA LBS) in a total of 80 surveys. The respondents of each area were as follows: 21 machinery suppliers, five machinery mechanics, eight farmers, two contractors, and four officers.

Figure 1 presents the research framework. The study framework was formed based on the literature review and various variables selected based on the study area's suitability. The selection of indicators is based on the objectives of the study. This study analyses the socio-economic effect on machinery and technical efficiencies in Malaysia's MADA and IADA BLAS paddy areas. The independent variables are a) socio-economic of the paddy machine supplier, b) machinery efficiency, and c) technical efficiency. These three variables affect paddy productivity. First, though, energy efficiency needs to be calculated to obtain machinery efficiency and technical efficiency. Therefore, the model is presented as $\mathrm{Y}=\mathrm{X} 1, \mathrm{X} 2, \mathrm{X} 3, \mathrm{X} 4, \mathrm{X} 5, \mathrm{X} 6$.

Model 1: Y1 - Socio-economic $=\mathrm{X} 1$

- Ages, X2 - Position, X3 - Education level, X4 - Experience, X5 - Training, X6 - Household 


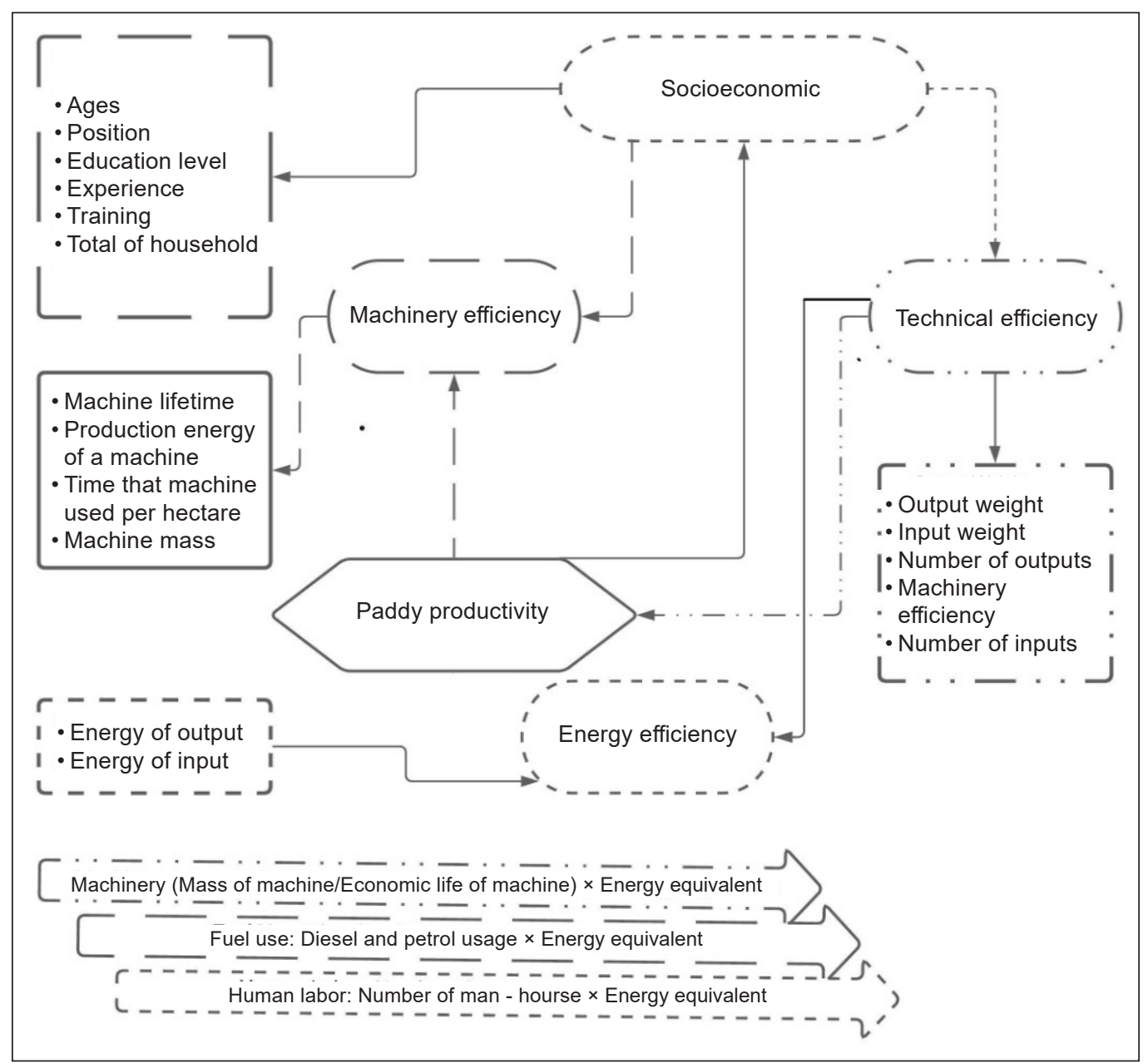

Figure 1. Research framework

Model 2: Y2 - Machine efficiency $=\mathrm{X} 1$

- Machine Mass, X2 - production energy of a machine, X3 - time that machine used per hectare, X4 - Machine lifetime Model 3: Y3 - Technical Efficiency $=$ X1 - Energy of Output, X2 - Energy of Input, X3 - Output Weight, X4 - Input Weights, X5 - Machinery Efficiency, X6 - Number of Outputs, X7 - Number of Inputs.

\section{Data Analysis}

The analysis began by discussing the socioeconomy of the paddy machine supplier to validate the data. An analysis was followed to determine the differences in machinery and farming efficiencies between MADA and IADA BLS. IBM SPSS statistical software (Version 22.0) was utilised to analyse the data. The quantitative data analysis is divided into three sections, namely, Energy Efficiency (EE), Machinery 
Efficiency (ME), and Technical Efficiency (TE); EE is used to calculate ME and TE.

Energy Efficiency: energy efficiency is determined by dividing energy output by energy inputs. Energy output is represented by paddy productivity-energy inputs represented by fuel, labour, and machinery. The measurement unit used is Megajoules/ hectare $(\mathrm{MJ} / \mathrm{ha})$, as shown in the equation below.

- Energy output $(O E)$ :

$O E=\left(M J h a^{-1}\right)=Y \times E E$

where $Y=$ Paddy Yield $\left(k g h a^{-1}\right)$, and $E E=$ Paddy Energy Equivalent $(M J$ $h a^{-1}$ )

- $\quad$ Energy input (IE):

$I E=(F E E E)+(H L E E)+(M E$

where $I E=$ Energy Input $\left(M J h a^{-1}\right)$, $F E=$ Fuel Use $\left(L h a^{-1}\right), H L=$ Human Labour Use $\left(H h a^{-1}\right), E E=$ Energy Equivalent for Each Input $(M J)$

(a) $F E\left(M J h a^{-1}\right) D+G$

where $\mathrm{D}=$ Amount of Diesel Usage $(L$ $\left.h a^{-1}\right) \times$ Energy Equivalent of Diesel (MJ $\left.L^{-1}\right), \mathrm{G}=$ Amount of Gasoline Usage $(L$ $\left.h \mathrm{a}^{-1}\right) \times$ Energy Equivalent of Gasoline $\left(M J L^{-1}\right)$

(b) Human Labor $(H L)$.

$H L\left(M J h a^{-1}\right)=$ Number of Man_hours $\left(h \mathrm{ha}^{-1}\right) \times$ Energy Equivalent of Human Labour $\left(M J h^{-1}\right)$

(c) Machinery $(M)$. $M\left(M J \mathrm{ha}^{-1}\right)=[$ Mass of machine $(\mathrm{kg}) /$ Economic Life of Machine (year)] $\times$
Energy Equivalent of Machine $\left(M J \mathrm{ha}^{-1}\right)$

- $\quad$ Energy efficiency (EE):

$$
E E=\frac{\text { Energy Output }\left(M J a^{-1}\right)}{\text { Energy Input }\left(M J h a^{-1}\right)}
$$

Energy value in paddy production is calculated by multiplying the energy output and input using relevant conversion factors. According to Pishgar-Komleh, Sefeedpari, and Rafiee (2011), paddy as output equals 17 $\left(M J \mathrm{~kg}^{-1}\right)$, while input including fuel (diesel 47.80, petrol $46.30\left(M J L^{-1}\right)$ and machinery 6.00-8.00 (MJ kg year $\left.{ }^{-1}\right)$ and human labour as an input equals $2\left(M J h^{-1}\right)$.

Machinery Efficiency: this study's first objective is to identify and analyse paddy machinery's efficiency in MADA and IADA BLS. In calculating the machinery efficiency, embedded energy is needed, and energy depreciation is assumed to produce the agricultural machinery during its economic lifetime. This study's machine type to determine $\mathrm{M}$ is tractor used to prepare the paddy area and harvester in harvesting activities. Machinery efficiency is calculated using the formula:

$$
M E=\frac{(G M t)}{T}
$$

where, $G=$ Machine Mass (kilogram), $M=$ production energy of a machine $\left(M J \mathrm{~kg}^{-1}\right)=$ $\frac{G}{T} E E, t=$ time that machine used per hectare ( $h h a^{-1}$ ), and $T=$ Machine lifetime (hour)

Technical Efficiency: Technical efficiency can be defined as a farmer's ability to produce maximum output given a set of inputs and technology levels. The 
TE equation is based on Nassiri and Singh (2009), the TE score in the presence of multiple inputs and output factors can be calculated by the ratio of the sum of weighted outputs y to the sum of weighted inputs $\mathrm{x}$ or in a mathematical expression as follows:

$$
T E_{j}=\frac{u_{1} y_{1}+u_{2} y_{2}+\cdots+u_{n} y_{n}}{v_{1} x_{1}+v_{2} x_{2}+\cdots+v_{m} x_{m}}=\frac{\sum_{r=1}^{n} u_{r} y_{r}}{\sum_{s=1}^{m} v_{s} x_{s}}
$$

Where, $y=$ Energy of Output, $x=$ Energy of Input, $u=$ Output Weight, $v=$ Input Weights, $u / v=\mathrm{ME}, r=$ Number of Outputs, and $s=$ Number of Inputs. The value of technical efficiency varies between zero and one. In this study, inputs were fuel, human labour, and machinery, and paddy production output. The value of inputs and output weights would be calculated during linear programming so that the value of technical efficiency approaches the maximum value.

\section{Descriptive Analysis}

Position, education, and machinery supplier training are directly related to paddy production in this study. The socio-economic status of farmers, machinery suppliers, officers, contractors, and machinery mechanics are related to production; therefore, ages, experiences, and households determine paddy production. Lifetime production energy, time is taken, and machine masses are the determinants for machinery efficiency. In contrast, energy equivalent for input, energy rate of the operation time, and the energy equivalent of output are the determinants for paddy production's technical efficiency (Effiong et al., 2015).

Primary data were obtained through semi-structured observations and in-depth interviews. The selection of respondents was based on the snowball sampling method. For example, the researchers went to each of the study areas and selected the first respondent at the study site and then followed by the next respondent introduced by the first respondent. The survey method aims to obtain observations without being constructed, designed, or discontinued. The descriptive analysis was utilised based on conducting 12 pilot surveys. After ensuring the surveys' quality, 40 respondents participated from each area (MADA and IADA LBS) in a total of 80 surveys. The face-to-face method was utilised in collecting the surveys. The interviews with officers intend to obtain more accurate and detailed information and discuss respondents' issues. Researchers use language that respondents can easily understand during the interview session. The interview method has no specific method of sample size calculation. Hence, a descriptive method was used to obtain the sample size needed (Miles et al., 2019).

\section{RESULTS}

\section{Socio-economic of Machine Suppliers}

Table 1 shows the socio-economic frequencies statistic and Chi-Square Tests of contribution, measurable to paddy production, according to Effiong et al. (2015). Comparison of socio-economic indicator results of machine suppliers 
showed that in the MADA, 34\% of the age of machinery suppliers varied between 25 to $34,33 \%$ varied between 35 to $44,25 \%$ varied between 45 to 54 , and $8 \%$ were within 55 to 64 years old. Meanwhile, in the IADA BLS, 34 and $33 \%$ were within 25 to 44 , while $11 \%$ were between 55 and 64 years old. In the MADA, the number of educated respondents through diploma, certificates, STPM, PMR, and UPSR were $4,3,1,3$, and 1 , respectively, while in the IADA BLS, the results were $6,1,1$, and 1 respondent, respectively. Some of the IADA BLS respondents managed to continue their studies to a higher level. Hence, all the machinery suppliers had an educational background. Furthermore, half of the MADA machinery suppliers were between

Table 1

Socio-economic frequencies statistic and chi-square tests

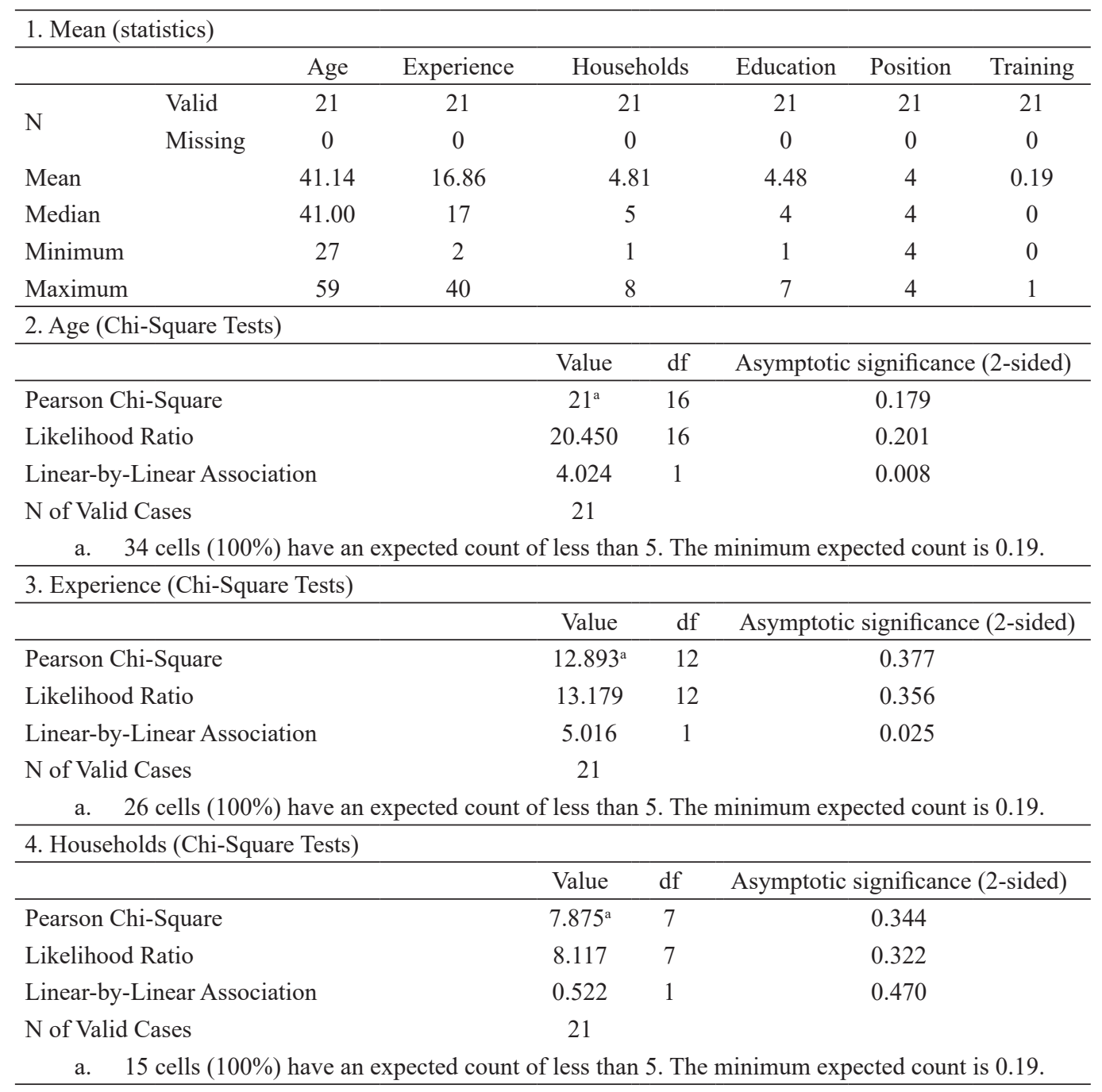


1 to 12 , and $33 \%$ were within 17 to 22 , while another $17 \%$ were between 30 to 43 years of experience in this industry.

On the other hand, $34 \%$ of the machinery supplier from the IADA BLS respondents were between 1 to $12,33 \%$ were between 17 to 22 , and $33 \%$ were between 30 to 43 years of experience. Furthermore. In the MADA, only $25 \%$ of the machinery suppliers trained before entering the industry, compared to only $11 \%$ in IADA BLS. Twentyfive percent of the machinery supplier's household numbers that need support in the MADA area had between 1 to $3 ; 58 \%$ had 4 to 6 , while only $17 \%$ had a range from 7 to 9 members in their family. While $11 \%$ from the IADA BLS were between 1 to $3,67 \%$ were between 4 to 6 , and another $22 \%$ were between 7 to 9 family members. Hence, both MADA and IADA BLS had many households ranging from 4 to 6 family members. These results align with Alam et al. (2010c), suggesting that socio-economic characteristics such as employment side, education level, and technology affect paddy farms' productivity. Land area and land ownership do not affect productivity but affect the cost and profitability of paddy farms. Thus, machinery technology was created to help the crop produce high production and improve rice yields.

Table 2 presents the socio-economic frequency statistic for MADA and IADA BLS, including age, position, education, experience, training, and household. The results showed that the respondent's mean age in MADA was 41 years old; the oldest respondent was 59, while the youngest was 27. In IADA, respondents' mean age was 36; the oldest respondent was 57, while the youngest was 27 years old. The education level, experience, training, and household in MADA mean were 4.65, 17.50, 0.35, and 4.55 , respectively. Most of them have their SPM as their education level and experience of about 17 years. While education level,

Table 2

Socio-economic frequency ftatistic for MADA and IADA BLS

\begin{tabular}{|c|c|c|c|c|c|c|c|c|c|c|c|c|}
\hline \multirow[t]{3}{*}{ Indicator } & \multicolumn{2}{|c|}{$\mathrm{N}$} & & & \multicolumn{2}{|c|}{ Mean } & \multicolumn{2}{|c|}{ Median } & \multicolumn{2}{|c|}{ Minimum } & \multicolumn{2}{|c|}{ Maximum } \\
\hline & & & & & $\frac{⿱ 亠 凶}{\Sigma}$ & 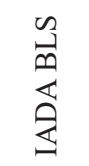 & 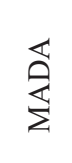 & 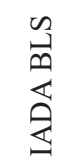 & 迡 & 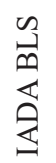 & 岁 & 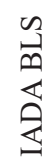 \\
\hline & $\stackrel{\Xi}{\frac{\Xi}{\pi}}$ & $\begin{array}{l}\stackrel{\infty}{\Xi} \\
. \infty \\
\sum\end{array}$ & 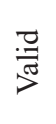 & 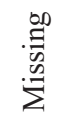 & & & & & & & & \\
\hline Age & 20 & 1 & 20 & 1 & 41.95 & 36.85 & 42 & 34.5 & 27 & 27 & 59 & 57 \\
\hline Position & 20 & 1 & 20 & 1 & 3.45 & 3.40 & 4 & 4 & 1 & 2 & 5 & 5 \\
\hline Education & 20 & 1 & 20 & 1 & 4.65 & 4.15 & 5.50 & 4 & 0 & 1 & 7 & 9 \\
\hline Experience & 20 & 1 & 20 & 1 & 17.5 & 14.35 & 17.5 & 10 & 1 & 0 & 43 & 40 \\
\hline Training & 20 & 1 & 20 & 1 & 0.35 & 0.40 & 0 & 0 & 0 & 0 & 1 & 1 \\
\hline Household & 20 & 1 & 20 & 1 & 4.55 & 4.50 & 5 & 5 & 1 & 1 & 7 & 8 \\
\hline
\end{tabular}


experience, training, and household in IADA BLS means were 4.15, 14.35, 0.40, and 4.5 , respectively.

\section{Analysis of Machinery Efficiency}

Machinery characteristic is essential in calculating machinery efficiency. The characteristic of each paddy machinery provides a valuable and different function. Table 3 illustrates the machinery characteristic for each activity, including land preparation, crop management, planting, and harvesting activities. Each machinery characteristic plays a vital role in contributing to each activity of paddy production. Besides, the characteristic of the machinery is needed to identify their efficiency. For land preparation, the capacity for the tractors is about 40 to 80 horsepower. The time taken for a crop for land preparation is about 1 to 2 hours. Even though the tractors are occupied with a high horsepower engine, they only could move slowly at a speed of 10 to $30 \mathrm{~km} /$ hour for a crop. Twentyfive percent of the transplanter at MADA has been modified by themselves. These modifications decrease the machinery's weight, increase the machinery's speed, and reduce the diesel consumption rate compared to the machinery in IADA BLAS that are not modified.

Table 3

Machinery characteristics for MADA and IADA BLS

\begin{tabular}{|c|c|c|c|c|c|c|c|}
\hline \multirow{2}{*}{\multicolumn{2}{|c|}{$\begin{array}{l}\text { 1. Land Preparation activity } \\
\text { Descrintion }\end{array}$}} & & & \multicolumn{4}{|c|}{ 3. Crop Management activity } \\
\hline & & MADA (\%) & IADA BLS (\%) & Description & & MADA (\%) & IADA BLS (\%) \\
\hline \multirow[t]{3}{*}{ Type } & New & 5 & 60 & Type & New & 100 & 100 \\
\hline & Modified & 90 & 40 & & Modified & 0 & 0 \\
\hline & Both & 5 & 0 & & Both & 0 & 0 \\
\hline \multirow{3}{*}{$\begin{array}{l}\text { Purchase } \\
\text { Source }\end{array}$} & Local & 35 & 60 & Purchase & Local & 55 & 75 \\
\hline & Import & 20 & 15 & Source & Import & 40 & 5 \\
\hline & Middleman & 25 & 25 & & Middleman & 5 & 20 \\
\hline \multirow{3}{*}{$\begin{array}{l}\text { Life } \\
\text { Expectancy } \\
\text { (Years) }\end{array}$} & $1-20$ & 55 & 45 & Life & Below 5 & 70 & 55 \\
\hline & $21-40$ & 20 & 15 & $\begin{array}{l}\text { Expectancy } \\
\text { (Years) }\end{array}$ & Above 5 & 30 & 45 \\
\hline & $41-60$ & 25 & 40 & Model & Drone & 15 & 0 \\
\hline \multirow[t]{3}{*}{ Model } & $\begin{array}{l}\text { Machinery } \\
\text { Ferguson }\end{array}$ & 55 & 0 & & Sprayer & 5 & 5 \\
\hline & Ford & 45 & 25 & & Kubota & 80 & 95 \\
\hline & Kubota & 0 & 75 & Horsepower & Below 5 & 45 & 90 \\
\hline \multirow{2}{*}{$\begin{array}{l}\text { Weight } \\
(\mathrm{kg})\end{array}$} & $2000-3000$ & 50 & 95 & / Capacity & Above 5 & 55 & 10 \\
\hline & $3000-4000$ & 50 & 5 & & Below 10 & 50 & 20 \\
\hline \multirow[t]{2}{*}{$\begin{array}{l}\text { Speed } \\
(\mathrm{km})\end{array}$} & Below 10 & 20 & 65 & $\begin{array}{l}\text { Weight } \\
(\mathrm{kg})\end{array}$ & Above 10 & 50 & 80 \\
\hline & Above 10 & 80 & 35 & Time taken & $0-1$ & 100 & 35 \\
\hline \multirow{2}{*}{$\begin{array}{l}\text { Time taken } \\
\text { (hour) }\end{array}$} & $0-1.5$ & 10 & 55 & (hour) & $1-2$ & 0 & 65 \\
\hline & $1.5-3$ & 90 & 45 & Total Diesel & Below 5 & 50 & 100 \\
\hline \multirow{2}{*}{$\begin{array}{l}\text { Horsepower / } \\
\text { Capacity }\end{array}$} & Below 80 & 95 & 75 & (litre) & Above 5 & 35 & 0 \\
\hline & Above 80 & 5 & 25 & & Battery & 15 & 0 \\
\hline \multirow{2}{*}{$\begin{array}{l}\text { Total Diesel } \\
\text { (litre) }\end{array}$} & $0-50$ & 100 & 65 & & & & \\
\hline & $50-100$ & 0 & 35 & & & & \\
\hline
\end{tabular}


Table 3 (continue)

\begin{tabular}{|c|c|c|c|c|c|c|c|}
\hline \multirow{2}{*}{\multicolumn{2}{|c|}{$\begin{array}{l}\text { 2. Planting activity } \\
\text { Description }\end{array}$}} & & & \multicolumn{4}{|c|}{ 4. Harvesting activity } \\
\hline & & MADA (\%) & IADA BLS (\%) & & Description & MADA (\%) & IADA BLS (\%) \\
\hline \multirow[t]{3}{*}{ Type } & New & 75 & 95 & \multirow[t]{3}{*}{ Type } & New & 0 & 20 \\
\hline & Modified & 25 & 0 & & Modified & 90 & 75 \\
\hline & Both & 0 & 5 & & Both & 10 & 5 \\
\hline \multirow{3}{*}{$\begin{array}{l}\text { Purchase } \\
\text { Source }\end{array}$} & Local & 85 & 70 & \multirow{3}{*}{$\begin{array}{l}\text { Purchase } \\
\text { Source }\end{array}$} & Local & 15 & 35 \\
\hline & Import & 10 & 20 & & Import & 70 & 30 \\
\hline & Middleman & 5 & 10 & & Middleman & 15 & 35 \\
\hline \multirow{2}{*}{$\begin{array}{l}\text { Life } \\
\text { Expectancy } \\
\text { (Years) }\end{array}$} & Below 5 & 100 & 40 & \multirow{3}{*}{$\begin{array}{l}\text { Life } \\
\text { Expectancy } \\
\text { (Years) }\end{array}$} & Below 10 & 25 & 5 \\
\hline & Above 5 & 0 & 60 & & $10-20$ & 5 & 15 \\
\hline \multirow[t]{3}{*}{ Model } & $\begin{array}{l}\text { Machinery } \\
\text { Ferguson }\end{array}$ & 0 & 0 & & $20-30$ & 35 & 75 \\
\hline & Ford & 0 & 0 & & Above 30 & 35 & 5 \\
\hline & Kubota & 100 & 100 & Model & New Holland & 100 & 100 \\
\hline \multirow{2}{*}{$\begin{array}{l}\text { Horsepower / } \\
\text { Capacity }\end{array}$} & Below 20 & 50 & 90 & & Others & 0 & 0 \\
\hline & Above 20 & 50 & 10 & Horsepower & Below 500 & 100 & 5 \\
\hline \multirow{3}{*}{$\begin{array}{l}\text { Weight } \\
(\mathrm{kg})\end{array}$} & Below 10 & 30 & 0 & / Capacity & Above 500 & 0 & 95 \\
\hline & Below 500 & 70 & 85 & Weight & Below 10000 & 5 & 10 \\
\hline & Above 500 & 0 & 15 & $(\mathrm{~kg})$ & Above 10000 & 95 & 90 \\
\hline \multirow{2}{*}{$\begin{array}{l}\text { Speed } \\
(\mathrm{km})\end{array}$} & Below 10 & 100 & 30 & Speed & $0-15$ & 60 & 80 \\
\hline & Above 10 & 0 & 70 & $(\mathrm{~km})$ & $15-30$ & 40 & 20 \\
\hline \multirow{2}{*}{$\begin{array}{l}\text { Time taken } \\
\text { (hour) }\end{array}$} & Below 1.5 & 100 & 35 & Time taken & Below 1 & 100 & 30 \\
\hline & Above 1.5 & 0 & 65 & (hour) & Above 1 & 0 & 70 \\
\hline \multirow{3}{*}{$\begin{array}{l}\text { Total Diesel } \\
\text { (litre) }\end{array}$} & $0-4$ & 50 & 55 & \multirow{3}{*}{$\begin{array}{l}\text { Total Diesel } \\
\text { (litre) }\end{array}$} & $10-20$ & 100 & 70 \\
\hline & $4-8$ & 0 & 45 & & $20-30$ & 0 & 30 \\
\hline & $8-10$ & 50 & 0 & & & & \\
\hline
\end{tabular}

Table 4 illustrates the frequencies statistic of machinery efficiency for tractor and harvester and machinery efficiency of MADA and IADA BLS. ME for MADA was $72 \%$, and IADA BLS was $61.3 \%$. Therefore, the larger the value of ME, the more efficient the machinery is.

\section{Analysis of Technical Efficiency}

The measurement of technical efficiency in agricultural production determines the efficiency level of production cost and inputs, such as labour, capital, technology, and output of paddy planting activities. Each activity has its own machinery cost. Table 5 presents machinery cost for
Table 4

Frequencies statistic of machinery for tractor and harvester in MADA and IADA BLS

\begin{tabular}{|c|c|c|c|}
\hline \multicolumn{4}{|c|}{ Machinery Efficiency for Tractor } \\
\hline & & ME MADA & ME IADA BLS \\
\hline \multirow{2}{*}{$\mathrm{N}$} & Valid & 20 & 20 \\
\hline & Missing & 0 & 0 \\
\hline \multicolumn{2}{|l|}{ Mean } & 6789.14 & 894.37 \\
\hline \multirow{2}{*}{\multicolumn{2}{|c|}{ Median }} & 7179.83 & 948.21 \\
\hline & & ME MADA & ME IADA \\
\hline \multicolumn{4}{|c|}{ Machinery Efficiency for Harvester } \\
\hline \multirow{2}{*}{$\mathrm{N}$} & Valid & 20 & 20 \\
\hline & Missing & 0 & 0 \\
\hline \multicolumn{2}{|l|}{ Mean } & 42864.10 & 4090.67 \\
\hline \multicolumn{2}{|l|}{ Median } & 20533.33 & 3733.33 \\
\hline \multicolumn{4}{|c|}{ Total Machinery Efficiency } \\
\hline & Total & Average \\
\hline \multicolumn{2}{|l|}{ MADA } & 993065 & 49653.23 \\
\hline \multicolumn{2}{|l|}{ IADA } & 99700.70 & 4985.04 \\
\hline
\end{tabular}


Table 5

Machinery cost for paddy production in MADA and IADA BLS

\begin{tabular}{|c|c|c|c|c|c|c|c|}
\hline \multicolumn{4}{|c|}{ 1. Land Preparation Activity } & \multicolumn{4}{|c|}{ 3. Crop Management Activity } \\
\hline \multicolumn{2}{|c|}{ Description } & \multirow{2}{*}{$\frac{\text { MADA }(\%)}{5}$} & \multirow{2}{*}{$\frac{\text { IADA BLS }(\%)}{55}$} & \multicolumn{2}{|c|}{ Description } & \multirow{2}{*}{$\frac{\text { MADA }(\%)}{50}$} & \multirow{2}{*}{$\frac{\text { IADA BLS }(\%)}{50}$} \\
\hline \multirow{2}{*}{ Service } & Below 1000 & & & \multirow{4}{*}{ Service } & Below 500 & & \\
\hline & Above 1000 & 95 & 45 & & Above 500 & 40 & 20 \\
\hline \multirow{2}{*}{ Repair } & Below 1000 & 10 & 45 & & New & 10 & 30 \\
\hline & Above 1000 & 90 & 55 & & Below 500 & 35 & 60 \\
\hline \multirow{2}{*}{ Wages } & $0-150$ & 100 & 80 & \multirow[t]{2}{*}{ Repair } & Above 500 & 35 & 10 \\
\hline & $150-300$ & 0 & 15 & & New & 30 & 30 \\
\hline \multirow{6}{*}{$\begin{array}{l}\text { Lubricant } \\
\text { Oil }\end{array}$} & Above 300 & 0 & 5 & \multirow{3}{*}{ Wages } & $0-150$ & 100 & 85 \\
\hline & Below 1000 & 70 & 55 & & $150-300$ & 0 & 5 \\
\hline & Above 1000 & 30 & 45 & & Above 300 & 0 & 10 \\
\hline & & & & \multirow{3}{*}{$\begin{array}{l}\text { Lubricant } \\
\text { Oil }\end{array}$} & Below 350 & 35 & 55 \\
\hline & & & & & $350-700$ & 40 & 45 \\
\hline & & & & & Above 700 & 25 & 0 \\
\hline \multicolumn{4}{|c|}{ 2. Planting Activity } & \multicolumn{4}{|c|}{ 4. Harvest Activity } \\
\hline \multicolumn{2}{|c|}{ Description } & MADA (\%) & IADA BLS (\%) & \multicolumn{2}{|c|}{ Description } & MADA $(\%)$ & IADA BLS (\%) \\
\hline \multirow{4}{*}{ Service } & Below 500 & 50 & 50 & \multirow[t]{4}{*}{ Service } & Below 2500 & 0 & 75 \\
\hline & Above 500 & 40 & 20 & & $2500-5000$ & 15 & 15 \\
\hline & New & 10 & 30 & & Above 5000 & 85 & 10 \\
\hline & Below 500 & 35 & 60 & & Below 2500 & 0 & 75 \\
\hline \multirow[t]{3}{*}{ Repair } & Above 500 & 35 & 10 & \multirow[t]{3}{*}{ Repair } & $2500-5000$ & 40 & 15 \\
\hline & New & 30 & 30 & & Above 5000 & 60 & 10 \\
\hline & $0-150$ & 100 & 85 & & Below 200 & 100 & 75 \\
\hline \multirow[t]{3}{*}{ Wages } & $150-300$ & 0 & 5 & \multirow[t]{3}{*}{ Wages } & $200-400$ & 0 & 5 \\
\hline & Above 300 & 0 & 10 & & Above 400 & 0 & 20 \\
\hline & Below 350 & 35 & 55 & & Below 1000 & 35 & 35 \\
\hline \multirow{2}{*}{$\begin{array}{l}\text { Lubricant } \\
\text { Oil }\end{array}$} & $350-700$ & 40 & 45 & \multirow{2}{*}{$\begin{array}{l}\text { Lubricant } \\
\text { Oil }\end{array}$} & $1000-2000$ & 0 & 65 \\
\hline & Above 700 & 25 & 0 & & Above 2000 & 65 & 0 \\
\hline
\end{tabular}

paddy production for land preparation, crop management, planting, and harvest activities. The results show that MADA had higher service costs than IADA BLS. In more detail, MADA recorded higher repair costs in land preparation activity, wages, and lower lubricant oil costs than IADA BLS. Therefore, machinery suppliers seek to minimise the machinery cost in order to maximise their profit. Because machine supplier profit depends on the paddy yield, the percentage's profits within 20 to 30 from machine rental based on its productivity.

Table 6 shows the average energy output and its frequencies statistic. MADA's average energy output is 10346.76 , while IADA BLS is 9941.85. Thus, MADA has more average energy output than IADA BLS. It is also indicated through MADA and IADA BLS, which are103.47 and 99.42, respectively. Thus, MADA seems to consume more energy compared to IADA BLS.

The results showed that the average energy efficiency for fuel and human labour in MADA and IADA BLS were 6092.953, 2850.535, and 15.27578, 11.44232, respectively. In this study, the inputs are the energy rate of operation time $=\mathrm{y}$ and the energy equivalent of input $=u$. While 
Table 6

Frequencies statistic of energy output and average energy output

\begin{tabular}{llcc}
\hline & & MADA & IADA BLS \\
\hline $\mathrm{N}$ & Valid & 20 & 20 \\
& Missing & 0 & 0 \\
Mean & & 103.47 & 99.42 \\
Median & & 97.84 & 105.02 \\
Average & Total & 2069.353 & 1988.37 \\
Energy & Average & 103.4676 & 99.41848 \\
Output & & & \\
\hline
\end{tabular}

the outputs are paddy productivity $=\mathrm{x}$ and energy equivalent of output $=\mathrm{v}$. In this case, $r$ $=40$ because, for input, there are two tractor activities for land preparation and harvesting machines. While $\mathrm{s}=20$. Hence, TE MADA $=305.52 / 2069.353=0.1476$, and TE IADA $\mathrm{BLS}=228.85 / 1988.37=0.1151$. Whenever the producer is on efficient production, TE $=1$. Otherwise, $\mathrm{TE}<1$. TE is a measure for the practical production level's distance (Juan et al., 2003). The inputs are fuel (petrol and diesel), human labour and machinery (tractor and harvester), while the output is the paddy yield. Overall, MADA seemed to be more efficient than IADA BLS because MADA's technical efficiency is closer to 1 rather than IADA BLS.

\section{DISCUSSION AND RECOMMENDATION}

MADA and IADA BLS respondents had an average of 41 years old, while MADA respondents had more experience than IADA BLS. Both areas' households range from 4 to 6 family members. MADA respondents seemed to be highly trained than IADA BLS; hence, MADA respondents had a better knowledge of machinery. It also could be confirmed by their education level, in which MADA respondents were more educated than IADA BLS. Socioeconomic is the link between economic activity and a social life that influences people by managing their wealth and income to improve the overall quality of life. Its aspects are fundamental to the development of society. The respondents' background was a determining factor directly related to machinery and productivity in agriculture. MADA's socio-economic respondents' status was slightly better than IADA BLS, increasing their living costs and wages and rent costs in MADA compared to IADA BLS. MADA was more efficient in using machinery in the agriculture sector than IADA BLS, in which IADA BLS had less productivity where it needs to be improved. Human labour and productivity were essential in increasing machinery efficiency. IADA BLS could get a better result in machinery efficiency if they increase labour force and productivity.

The productivity for MADA and IADA BLS showed that MADA's productivity was higher than IADA BLS. The same goes for energy outputs since IADA BLS had fewer energy outputs than MADA. Therefore, their productivity was higher than IADA BLS because they utilised more energy outputs. Besides, the results have shown that MADA machinery was more efficient compared to IADA BLS. Furthermore, MADA respondents used better technology efficiency than IADA BLS because it was higher and near the MADA's TE ratio1. It is because IADA BLS used fewer inputs compared to MADA input. On top of that, 
MADA used extra human labour and energy inputs compared to IADA BLS. Therefore, the higher inputs utilised, the closer the ratio to 1 , where technical efficiency varies between zero and one.

Farmers and machinery suppliers are advised to use the latest machinery model to improve machinery, and technical efficiency since newly renovated machinery will increase productivity. The old model of machinery should be replaced to ease farmers' jobs. Farmers or machinery suppliers can refer to authorities such as MADA authority to update the newly released model. Next is to choose machines that fit a particular purpose. One of the indications to choose suitable machines for fields is the machinery horsepower. For example, a tractor with a power of $100 \mathrm{hp}$ can be used for a large-sized farm, while a tractor with a power of $35 \mathrm{hp}$ is sufficient for small-sized farms. Paddy industry challenges related to paddy machinery and paddy planting activities, including the high cost of new machinery, expensive maintenance cost of old mechanics, hard to finding quality spare parts, challenging weather (soft soil), integrated water supply system, paddy field condition, small-sized/irregularly shaped paddy field plots, and paddy diseases. These factors resulted in an interruption of paddy production activities. They added additional costs that decreased their profit and jeopardised their financial status in paying their machine loans. Therefore, farmers and contractors are advised to use new machinery models equipped with new technologies, maintain their machinery, ensure the required services are carried out on time to maximise their machinery efficiency, improve land consolidation, irrigation drainage infrastructures, and hire experienced workers or farmers with a good background in operation machines.

Furthermore, the biggest challenges for technical efficiency are the high cost and increased use of fossil fuel. Fossil fuels are categorised as input energy needed for all machinery activity, from land preparation to harvesting. Moreover, from the depth interview with farmers and machinery suppliers, they stated they did not receive subsidies or government help on fossil fuels, which raises the production cost. Therefore, research and development in agricultural energy use, environment, and government subsidies could decrease production costs and improve paddy production.

\section{ACKNOWLEDGEMENT}

This research was fully funded by Short Term Grant, Universiti Sains Malaysia (USM) (304/PSOSIAL/6315147).

\section{REFERENCES}

Alam, M. M., Molla, R. I., \& Hossain, M. M. (2010a). Microentrepreneurship Development in Bangladesh: Achievements and Shortcomings. Saarbrucken, Germany: LAP Lambert Academic.

Alam, M. M., Siwar, C., Molla, R., Toriman, M., \& Talib, B. (2010b). Socio-economic impacts of climatic change on paddy cultivation: an empirical investigation in Malaysia. Journal of Knowledge Globalization, 3(2), 71-84. Retrieved from SSRN: https://ssrn.com/abstract=2941310

Alam, M. M., Siwar, C., Talib, B., \& Toriman, M. E. (2010c). The relationships between the socio-economic profile of farmers and paddy 
productivity in North-West Selangor, Malaysia. Asia-Pacific Development Journal, United Nations Economic and Social Commission for Asia and the Pacific, 18(1), 161-173.

Baharudin., S. A., \& Arshad, F. M. (2014). Energy use in paddy production: NKEA'S estate in MADA area. Economic and Technology Management Review, 9, 51-59.

Boniphace, N. S., Fengying, N., \& Chen, F. (2015). An analysis of smallholder farmers' socio-economic determinants for inputs use: A case of major rice producing regions in Tanzania. Russian Journal of Agricultural and Socio-Economic Sciences, 38(2), 41-55. https://doi.org/ 10.18551/ rjoas.2015-02.01

Chithranayana, R. D., \& Punyawardena, B. V. (2008). Identification of drought prone agro-ecological regions in Sri Lanka. Journal of the National Science Foundation of Sri Lanka, 36(2), 117-123. https://doi.org/10.4038/jnsfsr.v36i2.143

Dardak, R. A. (2019,). Malaysia's Agrofood Policy (NAP 2011-2020)-Performance and New Direction. FFTC Agricultural Policy. https:// ap.fftc.org.tw/article/1368

Effiong, J. B., Effiong, G. B., \& Udo, U. A. (2015). Socio-economic determinants of production of pro-vitamin a cassava varieties by farmers in Etim Ekpo local government area, Akwa Ibom state, Nigeria. Global Journal of Pure and Applied Sciences, 21(2), 105-111. https://doi. org/10.4314/gjpas.v21i2.2

Fahmi, Z., Samah, B. A., \& Abdullah, H. (2013). Paddy industry and paddy farmers well-being: A success recipe for agriculture industry in Malaysia. Asian Social Science, 9(3), 177-181. https://doi.org/10.5539/ass.v9n3p177

Garcia, G. (2008). The agricultural machinery industry in Argentina: From restructuring to internationalisation? CEPAL Review, 96, 223239. http://hdl.handle.net/11362/11348
Hussin, F., \& Mat, A. W. (2013). Socio-economic level of paddy farmers under the management of MADA: A case study in the Pendang District, Kedah. Journal of Governance and Development, 9, 79-90. http://repo.uum.edu.my/id/eprint/11903

Integrated Agricultural Development Area. (2019). Agriculture report. http://www.iadapp.gov.my/ Web/Page/Home.aspx

Juan, Z., Wu, J., \& McDonald, M. (2003). The socioeconomic impacts assessment of advanced convoy driving on motorway. Transportation Research Part A: Policy and Practice, 37(9), 731-747. https://doi.org/10.1016/S09658564(03)00045-4

Khai, H. V., \& Yabe, M. (2011). Technical efficiency analysis of rice production in Vietnam. International Society for Southeast Asian Agricultural Sciences, 17(1), 135-146. http:// issaas.org/journal/v17/01/journal-issaas-v17n115-khai_yabe.pdf

Khor, G. (2008). Food production strategies for improving household food security amidst rising food prices: Sharing the Malaysian experience. International Food Research Journal, 15(3), 249-257.

Livelihoods Outcome Indicator. (2013). Improving socio-economic conditions of paddy farmers in East Sri Lanka. Oxfam Great Britain. https:// oxfamilibrary.openrepository.com/bitstream/ handle/10546/303472/er-socio-economic-paddyfarmers-srilanka-effectiveness-review-010813summ-report-en.pdf?sequence $=2 \&$ isAllowed $=y$

Muda Agricultural Development Authority. (2020). Maklumat asas MADA [Basic information of MADA]. http://www.mada.gov.my/?page_ $\mathrm{id}=4115$ \&lang=en

Ministry of Agriculture and Food Industries. (2020). Policy and Strategic Planning Division, MAFI. https://www.mafi.gov.my/bahagian-dasar-danperancangan-strategik 
Mahidin, M. U. (2019). Selected agricultural indicators, Malaysia, 2019. Department of Statistics, Malaysia. https://www. dosm.gov.my/v1/index.php?r=column/ cthemeByCat\&cat=72\&bul_id=SEUxMEE3V FdBcDJhdUhPZVUxa2pKdz09\&menu_id=Z 0VTZGU1UHBUT1VJMFlpaXRRR0xpdz09

Man, N. (2009). Factors affecting the decision making in off farm employment among paddy farmers in Kemasin Semerak. Pertanika Journal of Social Sciences \& Humanities, (ISSN: 0128-7702), 17(1), 7-15.

Miles, M. B., Huberman, A. M., \& Saldana, J. (2019). Qualitative data analysis: A methods sourcebook (4th ed.). Sage.

Nassiri, S. M., \& Singh, S. (2009). Study on energy use efficiency for paddy crop using data envelopment analysis (DEA) technique. Applied Energy, 86(6-7), 1320-1325. https://doi.org/10.1016/j. apenergy.2008.10.007

Noor, Z. M., \& Hussein, M. A. (1986). The impact of free fertiliser subsidy scheme on economic efficiency of paddy farmers in West Malaysia. Malaysian Journal of Agricultural Economics, 3, 12-29.

Omar, S. C., Shaharudin, A., \& Tumin, S. A. (2019). The status of the paddy and rice industry in Malaysia. Khazanah Research Institute (KRI). http://www.krinstitute.org/assets/contentMS/ img/template/editor/20190409_RiceReport_ FullReport_Final.pdf

Pingali, P. (2007). Agricultural mechanisation: Adoption patterns and economic impact. In R. Evenson, \& P. Pingali (Eds.), Handbook of agricultural economics (Vol. 3, pp. 27792805). Elsevier. https://doi.org/10.1016/S15740072(06)03054-4
Pishgar-Komleh, S. H., Sefeedpari, P., \& Rafiee, S. (2011). Energy and economic analysis of rice production under different farm levels in Guilan province of Iran. Energy, 36(10), 5824-5831. https://doi.org/10.1016/j.energy.2011.08.044

Pryor, S. W., Smithers, J., Lyne, P., \& Antwerpen, R. v. (2017). Impact of agricultural practices on energy use and greenhouse gas emissions for South African sugarcane production. Journal of Cleaner Production, 141, 137-145. https://doi. org/10.1016/j.jclepro.2016.09.069

Rahmat, S. R., Firdaus, R. R., Shaharudin, S. M., \& Ling, L. Y. (2019). Leading key players and support system in Malaysian paddy production chain. Cogent Food \& Agriculture, 5(1), 1708682. https://doi.org/10.1080/23311932.20 19.1708682

Tewari, V. K., Kumar, A. A., Kumar, S. P., \& Nare, B. (2012). Farm mechanisation status of West Bengal in India. Basic Research Journal of Agricultural Science and Review, 1(6), 139-146.

The Star. (2019, January 23). Malaysia in bid to increase rice production by $5 \%$. The Star. https:// www.thestar.com.my/news/nation/2019/01/23/ malaysia-in-bid-to-increase-rice-productionby-5/

Yagi, H., \& Hayashi, T. (2021). Machinery utilization and management organization in Japanese rice farms: Comparison of single-family, multifamily, and community farms. Agribusiness, 37(2), 393408. https://doi.org/10.1002/agr.21656

Yu, J. W. (2013). Green design for concurrent engineering in agriculture machinery. Applied Mechanics and Materials, 367, 151-155. https://doi.org/10.4028/www.scientific.net/ AMM.367.151 